\title{
ENERGY INTENSITY AND GHG PRODUCTION OF CHOSEN PROPULSIONS USED IN ROAD TRANSPORT
}

Nowadays, there are more types of propulsions and fuels in road transport. This paper deals with the problem of their energy intensity and GHG emissions. The emissions can be classified as primary or secondary. The mixture of primary sources for the production of fuel or energy influence the final value of the ecological effectiveness of the propulsion. Methodology of the standard EN 16258:2012 was used for the estimation of this value.

Keywords: Energy intensity, GHG production, fuels.

\section{Introduction}

Energy consumption and greenhouse gas (GHG) emissions are a still growing problem in today's society. Environmental impacts of transport are unfavourable and they often have unavoidable character. Therefore, the efficiency of transport in relation to energy consumption and GHG emissions is constantly monitored at present. Recently, demand for the vehicles using alternatives representing the not commonly used fuels is constantly increasing. Besides conventional fuels such as gasoline or diesel, we can also observe the increased use of fuels such as CNG, electricity or combination of fuels [1, 2 and 3].

\section{Standard EN 16 258:2012}

This European standard specifies a general methodology for calculation and declaration of energy consumption and GHG emissions in connection with any services (cargo, passengers or both). It specifies general principles, definitions, system boundaries, methods of calculation, allocation rules (allocation, assignment) and recommendations on information to support standardized, accurate, reliable and verifiable declarations regarding energy consumption and greenhouse gas emissions associated with any freight service. It also contains examples of the use of these principles.

The calculation for one given transport service must be performed using the following three main steps:
- Step 1: Identification of the various sections of the service

- Step 2: Calculation of energy consumption and greenhouse gas emissions for each section

- Step 3: Sum of the results for each section [4].

The standard does not consider only the secondary emissions produced and energy consumed during combustion of the fuel (energy conversion from fuel to mechanical energy), but also primary emissions incurred in the extraction, production and distribution:

- ew - well-to-wheels energy factor for the defined fuel,

- gw - well-to-wheels emission factor for the defined fuel,

- et - tank-to-wheels energy factor for the defined fuel,

- gt - tank-to-wheels emission factor for the defined fuel.

Well-to-wheels factor covers also primary and secondary emissions and consumption. Somewhere, this factor is also called life-cycle analysis/assessment (LCA). Tank-to-Wheels factor considers only secondary emissions and consumption.

This standard specifies a general methodology for calculation and the declared value for the energetic factor and factor in greenhouse gas emissions must be selected in accordance with Annex A [4].

Emission gases are composed of several individual components (gases). Each of them has different chemical and physical properties and thus participates in environmental degradation differently. In order to compare emissions from different activities, fuels, vehicles when emissions have different tracks, it is necessary to designate one representative unit usable for the comparison. This is the $\mathrm{CO}_{2}$ equivalent, which is a measure of impact of

\footnotetext{
* ${ }^{1}$ Tomas Skrucany, ${ }^{1}$ Stefania Semanova, ${ }^{2}$ Tomasz Figlus, ${ }^{1}$ Branislav Sarkan, ${ }^{1}$ Jozef Gnap

${ }^{1}$ Department of Road and Urban Transport, Faculty of Operation and Economics of Transport and Communications, University of Zilina, Slovakia

${ }^{2}$ Department of Automotive Vehicle Construction, Faculty of Transport, Silesian University of Technology, Katowice, Poland

E-mail: tomas.skrucany@fpedas.uniza.sk
} 
EN standard factors [authors based on EN 16 258:2012

\begin{tabular}{|c|c|c|c|c|c|c|c|c|c|c|}
\hline \multirow{4}{*}{ Fuel } & \multicolumn{4}{|c|}{ Energy factor } & \multicolumn{6}{|c|}{ Emission factor } \\
\hline & \multicolumn{2}{|c|}{$\begin{array}{c}\text { Tank-to-wheels } \\
\left(\mathrm{e}_{\mathrm{t}}\right)\end{array}$} & \multicolumn{2}{|c|}{$\begin{array}{l}\text { Well-to-wheels } \\
\left(\mathrm{e}_{\mathrm{w}}\right)\end{array}$} & \multicolumn{3}{|c|}{ Tank-to-wheels $\left(g_{t}\right)$} & \multicolumn{3}{|c|}{ Well-to-wheels $\left(\mathrm{g}_{\mathrm{w}}\right)$} \\
\hline & \multirow{2}{*}{$\begin{array}{c}\mathrm{MJ} / \\
\mathrm{kg}\end{array}$} & \multirow{2}{*}{ MJ/l } & \multirow{2}{*}{$\begin{array}{c}\text { MJ/ } \\
\text { kg }\end{array}$} & \multirow{2}{*}{$\mathrm{MJ} / \mathrm{I}$} & & & & & & \\
\hline & & & & & $\mathrm{gCO}_{2} \mathrm{e} / \mathrm{MJ}$ & $\mathrm{kgCO}_{2} \mathrm{e} / \mathrm{kg}$ & $\mathrm{kgCO}_{2} \mathrm{e} / \mathrm{l}$ & $\mathrm{gCO}_{2} \mathrm{e} / \mathrm{MJ}$ & $\mathrm{kgCO}_{2} \mathrm{e} / \mathrm{kg}$ & $\mathrm{kgCO}_{2} \mathrm{e} / \mathrm{l}$ \\
\hline Gasoline & 43.2 & 32.2 & 50.5 & 37.7 & 75.2 & 3.25 & 2.42 & 89.4 & 3.86 & 2.88 \\
\hline $\begin{array}{l}\text { Mixture Gasoline/ } \\
\text { Ethanol 95/5 }\end{array}$ & 42.4 & 31.7 & 51.4 & 38.4 & 72.6 & 3.08 & 2.30 & 88.4 & 3.74 & 2.80 \\
\hline Diesel & 43.1 & 35.9 & 51.3 & 42.7 & 74.5 & 3.21 & 2.67 & 90.4 & 3.90 & 3.24 \\
\hline Biodiesel & 36.8 & 32.8 & 76.9 & 68.5 & 0 & 0 & 0 & 58.8 & 2.16 & 1.92 \\
\hline $\begin{array}{l}\text { Liquid petroleum gas } \\
\text { (LPG) }\end{array}$ & 46.0 & 25.3 & 51.5 & 28.3 & 67.3 & 3.10 & 1,70 & 75.3 & 3.46 & 1.90 \\
\hline $\begin{array}{l}\text { Compressed natural gas } \\
(\mathrm{CNG})\end{array}$ & 45.1 & & 50.5 & & 59.4 & 2.68 & & 68.1 & 3.07 & \\
\hline $\begin{array}{l}\text { Marine diesel oil } \\
\text { (MDO) }\end{array}$ & 43.0 & 38.7 & 51.2 & 46.1 & 75.3 & 3.24 & 2.92 & 91.2 & 3.92 & 3.53 \\
\hline
\end{tabular}

specific emissions and likens it to the impact of $\mathrm{CO}_{2}$. The label is $\mathrm{CO}_{2 \mathrm{e}}$ (equivalent) [5, 6 and 7].

\section{Equivalent $\mathrm{CO}_{2}, \mathrm{CO}_{2 \mathrm{e}}$}

It is a universal measure of the amount of greenhouse gas (carbon dioxide, methane, nitrous oxide, etc.) which has the same effect on the climate system as carbon dioxide itself. It takes into account the exact degree of the impact of the greenhouse effect in the atmosphere generated by individual components of greenhouse gases. For example, one tonne of methane has 21 times greater degree of the greenhouse effect than one tonne of $\mathrm{CO}_{2}$ and thus 1 tonne of methane represents the value of $21 \mathrm{t}$ $\mathrm{CO}_{2}$. This synthetic variable was created for the purpose of high explanatory power when comparing production of emissions from different industries, different sources and different fuels with varying composition [8, 9, 10 and 11].

Table 1 shows that not only the technical aspect of a vehicle and its efficiency to convert fuel energy to mechanical work but also the amount of energy spent on production, acquisition and distribution of fuel have an effect on the overall energy consumption. This represents a so-called LCA factor (a factor of a life cycle) which includes the well-to-wheels declaration method. The table also shows that when comparing direct energy consumption of a vehicle it is possible to achieve lower value of $e$ during combustion of biodiesel than during combustion of diesel. In the end, however, biodiesel is significantly worse when we compare the value of $e_{w}$. Of course, it is also necessary to take into account the amount of fuel consumption during vehicle operation in that comparison. The consumption varies according to the amount of energy contained in the fuel and efficiency of fuel combustion. Therefore, the extent of energy intensity of a certain vehicle may not be clear from the table. It is necessary to know the actual fuel consumption of the vehicle.

\section{Electricity as the propulsion of road vehicles}

Nowadays, the electric propulsion vehicles are increasingly penetrating the market. This propulsion is presented as clean and very acceptable for the environment because it produces no direct emissions. This fact predetermines these vehicles mainly for the use in urban areas and the surroundings in which emissions produced by road transport during combustion of fossil fuels are undesirable. However, to objectively compare different types of propulsion, secondary emissions should be also taken into account and thus the way of electricity production. Composition of the primary sources used for production of electricity and its conversion efficiency mainly influence the production of greenhouse gases. These two attributes are different in relation to regions of the production. If we consider regions as states, significant differences may be observed between individual countries.

Energy and emission factor $\left(\mathrm{e}_{\mathrm{w}}, \mathrm{g}_{\mathrm{w}}\right)$ reflect a partial loss of production and distribution of power/energy in the chain:

1. energy mixture used in the manufacture of electric energy,

2. efficiency of power, various energy sources,

3. transfer efficiency (distribution) of electricity supply to the final consumer.

This fact implies that the effectiveness (efficiency) of electric energy is directly related to the power production technology, 
the composition and proportions of individual resources and the effectiveness of its distribution.

\section{Primary sources of electric energy in Slovakia 2013}

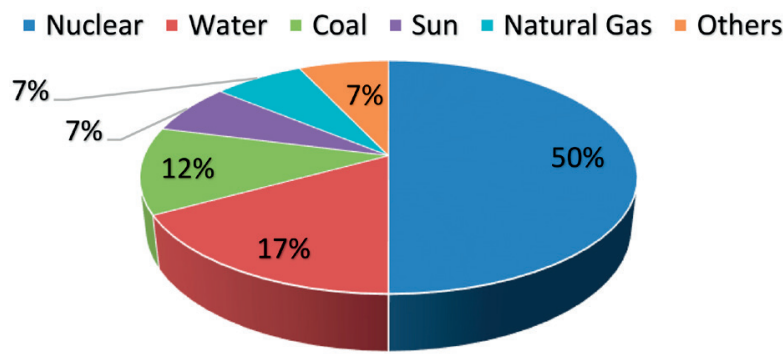

Fig. 1 Shares of the resources in the production of electricity [12 and 13]

Energy efficiency in electricity production can be calculated as a weighted arithmetic mean of primary resources and efficiency in power by various energy sources. Weight values represent the proportions of the various sources. Efficiency values were chosen on the basis of national regulation in Slovakia, which prescribes their height (Fig. 1).

Produced energy is delivered to consumers through the transmission system. This process took place without losses and efficiency of power transmission network in Slovakia was about $93 \%$ last year [12 and 13].

The efficiency of vehicle system represent transmission losses from conduction through the whole vehicle traction system losses from the vehicle energy source to the wheels. The efficiency of this process is approximately $90 \%$. So, the overall energy efficiency of supplied power for rail transport in Slovakia is:
$\eta_{C E}=\eta_{V} \cdot \eta_{P} \cdot \eta_{D P}=\left(\sum\left(\eta_{Z i} \cdot p_{Z i}\right) / p_{Z}\right) \cdot \eta_{P} \cdot \eta_{D P}$

where: $\eta_{\mathrm{CE}}$ overall energy efficiency [-]

$\eta_{\mathrm{V}}$ efficiency of power energy [-]

$\eta_{\mathrm{P}}$ power transfer efficiency [-]

$\eta_{D P}$ efficiency of vehicle system [-]

$\eta_{\mathrm{Zi}}$ effectiveness of a particular primary source [-]

$\mathrm{p}_{\mathrm{Zi}}$ share of a given resource in the production of electric power [-]

$\mathrm{p}_{\mathrm{z}}$ sum of partial fractions of the individual sources [-]

The value of overall energy efficiency is 0.34 . With regard to the value calculated on the basis of statistical data, but when compared, for example, with that in Germany, this value is the same.

\section{Production of emissions and electric energy}

The same procedure as for calculating the total energy efficiency can be used for the calculation of emission production. The procedure would be the same; it would be based on a share of individual sources and their emissions. We get the resulting value also by using the arithmetic mean. An easier way, however, is the use of so-called emission factor. This value is calculated for each country and includes the overall efficiency of electricity in a particular country, in addition to efficiency of the vehicle. Therefore, this emission factor should be used when comparing the country without a lengthy search for sub efficiency and emissions [14, 15 and 16].

LCA emission factors of EU-27 countries [17]

Table 2

\begin{tabular}{|l|c|c|c|}
\hline Country & LCA emission factor $\left(\mathrm{tCO}_{2 \mathrm{e}} / \mathrm{MWh}\right)$ & Country & LCA emission factor $\left(\mathrm{tCO}_{2 \mathrm{e}} / \mathrm{MWh}^{\mathrm{N}}\right.$ \\
\hline Austria & 0.310 & Sweden & 0.079 \\
\hline Belgium & 0.402 & Bulgaria & 0.906 \\
\hline Germany & 0.706 & Cyprus & 1.019 \\
\hline Denmark & 0.760 & Czech Republic & 0.802 \\
\hline Spain & 0.639 & Estonia & 1.593 \\
\hline Finland & 0.418 & Hungary & 0.678 \\
\hline France & 0.146 & Lithuania & 0.174 \\
\hline UK & 0.658 & Latvia & 0.563 \\
\hline Greece & 1.167 & Poland & 1.185 \\
\hline Ireland & 0.870 & Romania & 1.084 \\
\hline Italy & 0.708 & Slovenia & 0.602 \\
\hline Netherlands & 0.716 & Slovakia & 0.353 \\
\hline Portugal & 0.750 & EU-27 average & 0.578 \\
\hline
\end{tabular}

For Slovakia, this value represents $0.353 \mathrm{tCO}_{2 \mathrm{~d}} / \mathrm{MWh}$, what is $90.81 \mathrm{gCO}_{2 \mathrm{e}} / \mathrm{MJ}$. 


\subsection{Calculation and equations}

To calculate the total energy consumption, the consumed amount of fuel should be multiplied by an emission factor for that fuel from Appendix A of the standard.

$E_{C V}=S_{100 k m} \cdot \frac{1}{100} \cdot e_{w}[\mathrm{MJ}]$

where: $\mathrm{E}_{\mathrm{CV}}$ total energy consumption by a vehicle $[\mathrm{MJ}]$

$\mathrm{S}_{100 \mathrm{~km}}$ vehicle fuel consumption per $100 \mathrm{~km}[1 / 100 \mathrm{~km}]$

$e_{w}$ energetic factor "wtw" for the defined fuel [MJ/1]

For GHG production the same procedure is applied as for the energy calculation, but the consumed amount of energy in fuel is multiplied by the emission factor from the EN standard.

$G_{P V}=S_{100 k m} \cdot \frac{1}{100} \cdot g_{w}\left[\mathrm{gCO}_{2 \mathrm{e}} / \mathrm{km}\right]$

where:

$\mathrm{G}_{\mathrm{PV}}$ amount of emissions produced by a vehicle $\left[\mathrm{gCO}_{2 \mathrm{e}} / \mathrm{km}\right]$

$\mathrm{g}_{\mathrm{W}}$ emission factor for the defined fuel $\left[\mathrm{kgCO}_{2 \mathrm{e}} / 1\right.$ or $\left.\mathrm{kg} \mathrm{CO}_{2 \mathrm{e}} / \mathrm{kg}\right]$

Above written equations are valid for emission production of a vehicle driven by some type of fuel, but not for electrically powered vehicles. Next equations are used for them.

$E_{C E V}=\left[S_{100 k m} \cdot \frac{1}{100} \cdot 3.6 *\right] \cdot \eta_{C E}[\mathrm{MJ}]$

where:

$\mathrm{E}_{\mathrm{CEV}}$ total energy consumption by an electric vehicle [MJ]

$\mathrm{S}_{100 \mathrm{~km}}$ vehicle primary energy consumption per $100 \mathrm{~km}[\mathrm{kWh}$ $/ 100 \mathrm{~km}]$

$\mathrm{e}_{\mathrm{w}} \quad$ energy factor "wtw" for defined fuel [MJ/1]

$\eta_{C E}$ overall energy efficiency [-] (eq. 1)

* for the fuel $\mathrm{e}_{\mathrm{w}}$ factor is used, for electric traction in $\mathrm{kWh} 3.6$ coefficient is used (energy unit conversion from $\mathrm{kWh}$ to $\mathrm{MJ}$ )
We used LCA emission factor to calculate the amount of emissions produced (Table 2). This factor already counts with efficiency of the electric power production, so the input for this equation is only primary energy consumption of the chosen vehicle. Also the conversion coefficient of electric units is not used, because this factor value is calculated for $1 \mathrm{kWh}$ of consumed electricity.

$G_{P E V}=\left[S_{100 \mathrm{~km}} \cdot \frac{1}{100}\right] \cdot g_{L C A}\left[\mathrm{gCO}_{2 \mathrm{e}} / \mathrm{km}\right]$

where:

$\mathrm{G}_{\mathrm{PEV}}$ amount of emissions produced by an electric vehicle $\left[\mathrm{gCO}_{2 \mathrm{e}} / \mathrm{km}\right]$

$\mathrm{g}_{\mathrm{LCA}}$ emission factor for electric power $\left[\mathrm{kgCO}_{2 \mathrm{e}} / \mathrm{kWh}\right]$ (Table 2).

\section{Practical calculation}

If we want to use a methodology for the calculation of energy intensity and GHG production in transport for passenger cars with different fuel types, it is suitable to use the following example.

Let us consider a vehicle frequently used in Slovakia and the Czech Republic which represents the middle class vehicle of an unnamed manufacturer who offers this type of vehicle with three types of propulsion - gasoline, gasoline/CNG and diesel with approximately the same engine power. Vehicle mark and model are not important in this case, but performance, weight parameters and fuel consumption of the vehicle are relevant. Curb weight of the vehicle is about $1500 \mathrm{~kg}$ and the vehicle engine power is about $80 \mathrm{~kW}$. For this type of the vehicle, fuel consumption may range from 6 to 7 litres of gasoline per $100 \mathrm{~km}$; in the case of diesel engines it may be from 5 to 6 litres per $100 \mathrm{~km}$ and the vehicle consumption with CNG propulsion is about 5 $\mathrm{kg} / 100 \mathrm{~km}$. Results of these calculations are in the table below (Table 3).

Fuel and energy consumptions stated by the manufacturer were used for the purposes of this calculation. The consumption

Calculation of energy consumption and GHG emissions [calculations according to 4 and 17]

Table 3

\begin{tabular}{|c|c|c|c|c|c|}
\hline \multirow[b]{2}{*}{ Fuel } & \multirow[b]{2}{*}{$\begin{array}{l}\text { Average fuel consumption } \\
\quad(l, \mathrm{~kg}, \mathrm{kWh} / 100 \mathrm{~km})\end{array}$} & \multicolumn{2}{|c|}{ primary } & \multicolumn{2}{|c|}{ primary + secondary } \\
\hline & & $\begin{array}{l}\text { Energy consumption } \\
\qquad(\mathrm{MJ} / \mathrm{km})\end{array}$ & $\begin{array}{c}\text { Production } \mathrm{CO}_{2 e} \\
(\mathrm{~g} / \mathrm{km})\end{array}$ & $\begin{array}{c}\text { Energy } \\
\text { consumption } \\
(\mathrm{MJ} / \mathrm{km})\end{array}$ & $\begin{array}{c}\text { Production } \mathrm{CO}_{2 e} \\
(\mathrm{~g} / \mathrm{km})\end{array}$ \\
\hline Gasoline & 5.6 & 1.80 & 136 & 2.11 & 161 \\
\hline $\mathrm{CNG}$ & 4.4 & 1.98 & 118 & 2.20 & 135 \\
\hline Diesel & 4.4 & 1.58 & 117 & 1.88 & 143 \\
\hline electricity* & 20 & 0.72 & 0 & 2.12 & $65 / 149$ \\
\hline hybrid** & 4 & 1.29 & 97 & 1.51 & 115 \\
\hline
\end{tabular}

* this applies only for the consumed electric energy produced in the SR/CZ

** variable value; it depends on regime of vehicle operation (city, highways); the used type of hybrid technology 
was measured according to the standard. Consumption indicated by the manufacturer in the combined NEDC cycle is taken into account.

For comparison of other propulsion systems which are nowadays used in passenger cars, we chose the vehicles of the same category propelled by alternative technologies such as hybrid propulsion of gasoline/electric energy or fully electric cars.

The chart below (Fig. 2) shows the graphical results of the calculation of energy intensity and GHG emissions according to the methodology of the mentioned standard.

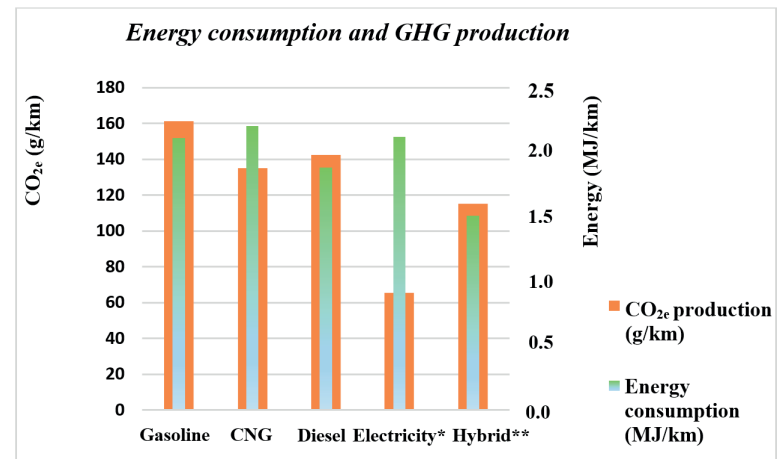

* this applies only for the consumed electric energy produced in the SR/CZ

** variable value; it depends on regime of vehicle operation (city, highways); the used type of hybrid technology

Fig. 2 Energy consumption and GHG production

The results in the chart (Fig. 2) represent energy consumption and GHG production from a global aspect, thus primary as well as secondary impacts are taken into account. CNG is the cleanest from hydrocarbon fuels in terms of GHG production. In terms of energy consumption, however, it represents the least efficient fuel despite the fact that its production/modification is not subject to such procedures as in the case of gasoline or diesel. This is caused by a large content of energy in $1 \mathrm{~kg}$ of $\mathrm{CNG}$ and thus engines combusting $\mathrm{CNG}$ achieve lower efficiency than the engines designed for gasoline or diesel.

When comparing the mentioned five vehicle propulsions, it also necessary to particularly look at electric vehicles and vehicles with hybrid technology of propulsion. The resulting energy consumption (primary as well as secondary) of electric vehicles greatly depends on the country in which those vehicles are driven or the country from which the electricity is used. In this regard, the way of electricity production is important, and thus the efficiency during its production and GHG emissions already in the process of its acquisition. This can be seen when comparing the results of the same electric vehicle operated in Slovakia or the Czech Republic. Therefore, the following part of the paper deals with this issue [10,12 and 13] and the results are presented in the next Table 4 .
In the case of hybrid vehicles, the resulting energy consumption may vary widely and thus also production of emissions, because this type of propulsion reaches greater differences in terms of the regime of vehicle operation. Vehicle consumption within urban areas may represent a very small amount. But, the use of hybrid vehicles on highways may result in equal or even higher vehicle consumption compared to comparable vehicles with conventional propulsion for combusting hydrocarbon fuels [18, 19 and 20].

Comparison of $\mathrm{CO}_{2 \mathrm{e}}$ in the selected $\mathrm{EU}$ countries

[calculations according to 4 and 17]

Table 4

\begin{tabular}{|c|c|c|c|}
\hline Country & $\begin{array}{c}\text { Vehicle energy } \\
\text { consumption } \\
(\mathbf{k W h} / 100 \mathrm{~km})\end{array}$ & $\begin{array}{c}\text { Tank-to-wheels } \\
\text { Production } \mathrm{CO}_{2 e} \\
(\mathrm{~g} / \mathbf{k m})\end{array}$ & $\begin{array}{c}\text { Well-to-wheels } \\
\text { Production CO } \\
(\mathbf{g} / \mathbf{k m})\end{array}$ \\
\hline Estonia & & & 318.6 \\
Slovakia & 20 & 0 & 70.6 \\
Germany & & & 141.2 \\
EU - 27 & & & 115.6 \\
Sweden & & & 15.8 \\
\hline
\end{tabular}

Figure 3 graphically shows the results of the calculation of GHG production of different propulsions. The left side of the chart contains data on the fuels which are combusted in combustion engines and hybrid technology. The results of these fuels are relatively similar. There are only minor differences. The values are in the range about $115-160 \mathrm{gCO}_{2 \mathrm{e}} / \mathrm{km}$ and the average value is $138 \mathrm{gCO}_{2 \mathrm{e}} / \mathrm{km}$ (the left orange bar in the chart).

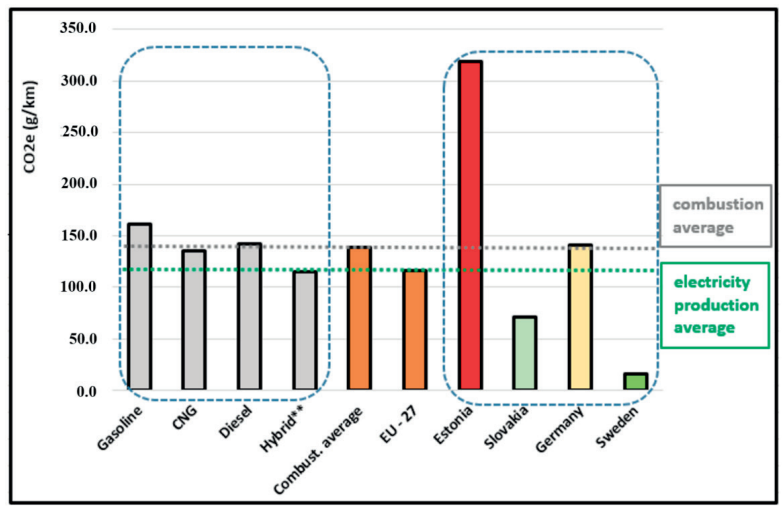

Fig. 3 Comparison of GHG production for different types of propulsion of road vehicles

On the right side of the chart (Fig. 3), there are results of the vehicles propelled by electric energy produced in different EU states. These results are greatly different. In Estonia, GHG emissions during electricity production represent the highest value from EU states. Compared to Sweden, the GHG production is approximately 20 times lower. This is caused by the fact that 
both states use different sources. If fossil fuels are mainly used in electricity production (e.g. Estonia, Poland, Greece), electric energy will never be "green" and it will reach higher values of GHG production than conventional fuels for combustion engines. In countries such as Sweden and Austria, hydroelectric and nuclear power plants and renewable resources are mainly used and thus this way of electricity production is indeed environmentally acceptable.

\section{Conclusion}

The results presented in this paper show the difficulty in comparing energy consumption and GHG production in transport when using different fuels. This is caused by chemical composition of the fuel, the form of energy contained in it, its production, distribution and storage. Thus not only the fuel itself and efficiency of its energy conversion in a vehicle (fuel consumption of a vehicle) have impacts on the environment, but also all procedures used for acquisition and processing of the fuel and its environmental friendliness must be considered. Another very important factor in the assessment of the effects of selected vehicle propulsions on the environment is the place of production, especially in the case of electric energy. Large differences in primary sources and efficiency of different technologies used in electricity production cause significant differences in energy efficiency and GHG production. These differences may be observed in different countries and even regions.

\section{References}

[1] KALINA, T., JURKOVIC, M., GROBARCIKOVA, A.: LNG - Great Opportunity for the Inland Water Transport. Proc. of the 19 intern. Scientific conference Transport Means 2015, October 22-23, 2015, 489-492, Kaunas University of Technology.

[2] RIEVAJ, V., MOKRICKOVA, L., RIEVAJ, J.: Impact of Driving Techniques on Fuel Consumption. Communications - Scientific Letters of University of Zilina, vol. 18, No. 2, 2016, 72-75.

[3] RIEVAJ, V. et al: The Impact of Air Resistance on the Fuel Consumption in Real Conditions within the Transport Operation. Communications - Scientific Letters of the University of Zilina, vol. 18, No. 2, 2016, 57-61.

[4] European standard EN 16 258:2012. Methodology for Calculation and Declaration of Energy Consumption and GHG Emissions of Transport Services (freight and passengers).

[5] KUCERA, L., GAJDAC, I., MRUZEK, M.: Simulation of Parameters Influencing the Electric Vehicle Range. Communications Scientific Letters of the University of Zilina, vol. 18, No. 1A, 2016, 59-63.

[6] KNEZ, M., MUNEER, T., JEREB, B., CULLINANE, K.: The Estimation of a Driving Cycle for Celje and a Comparison to other European Cities. Sustainable Cities and Society, vol. 11, 2014, 56-60.

[7] KNEZ, M., JEREB, B., OBRECHT, M.: Factors Influencing the Purchasing Decisions of Low Emission Cars: A Study of Slovenia. Transportation Research, Part D, Transport and Environment, vol. 30, 2014, 53-61.

[8] ISO 14064:2006. International standard for GHG Emissions Inventories and Verification. Part 1: Specification with guidance at the organization level for quantification and reporting of GHG emissions and removals.

[9] LISCAK, S., RIEVAJ, V., SULGAN, M.: Vehicle's Technical Condition and Emission. Eksploatacja i Niezawodnosc - Maintenance and Reliability, 37(1), 2008, 61-63.

[10] KALINA, T., JURKOVIC, M., BINOVA, H., GARDLO, B.: Water Transport - The Challenge for the Automotive Industry in Slovakia. Communications - Scientific Letters of of the University of Zilina, vol. 18, No. 2, 2016, 26-29.

[11] BARTH, M., BORIBOONSOMSIN, K.: Energy and Emissions Impacts of a Freeway-Based Dynamic Eco-Driving System. Transportation Research, Part D: Transport and Environment, vol. 14, No. 6, 400-410.

[12] SKRUCANY, T. et al.: Software Simulation of an Energy Consumption and GHG Production in Transport. Communications in Computer and Information Science, vol. 531, 2015, 151-160.

[13] SKRUCANY, T., GNAP, J.: Energy Intensity and Greenhouse Gases Production of the Road and Rail Cargo Transport using a Software in Simulate the Energy Consumption of a Train. Proc. of $14^{\text {th }}$ intern. Conference on Transport Systems Telematics: Telematics Support of Transport, TST 2014, Berlin: SPRINGER-VERLAG, 2014, 263-272.

[14] HROMADKO, J., MILlER, P., HONIG, V.: Use of the Vehicle Movement Model to Determine Economic and Environmental Impact Caused by Separate Vehicles. Eskploatacja i Niezawodnosc - Maintenance and Reliability, 1: 70-73, 2009.

[15] VAISHNAV, P.: Greenhouse Gas Emissions from International Transport. Issues in Science and Technology, vol. 30, No. 2, 2014, 25-28. 
[16] GARCIA-AlVAREZ, A., PEREZ-MARTINEZ, P. J., GONZALEZ-FRANCO, I.: Energy Consumption and Carbon Dioxide Emissions in Rail and Road Freight Transport in Spain: A Case Study of Car Carriers and Bulk Petrochemicals. J. of Intelligent Transportation Systems, Philadelphia, 2013, ISSN 1547-2450.

[17] Technical annex to the SEAP template instructions document: The emission factors. Document of the European Commission.

[18] DAVILA, A.: Report on Fuel Consumption. Project 233683 SARTRE, ECE, 2013.

[19] KALINA, T., GROBARCIKOVA, A.: LNG as Alternative Fuel for European Transport System. Communications - Scientific Letters of the University of Zilina, vol. 16, No. 2, 2014, 70-76.

[20] CABAN, J., DROZDZIEL, P., BARTA, D., LISCAK, S.: Vehicle Tire Pressure Monitoring Systems, Diagnostyka - Diagnostics, vol. 15, No. 3, 2014, 11-14. 